\title{
Does evolution compromise Christian faith? R. J. Asher's Evolution and Belief
}

\author{
Egbert Giles Leigh Jr
}

Evolution and Belief: Confessions of a Religious Paleontologist, by Robert J. Asher. Cambridge, England: Cambridge University Press, 2012. Pp. xxiii +300 . H/b $\$ 24.99$.

In this book, Robert Asher reviews some of the overwhelming evidence for evolution, explains why evolutionary biology should pose no threat to Christian faith, and refutes oft-repeated criticisms of evolution by natural selection that many non-biologists find convincing. Asher does a wonderful job with the evidence for evolution, although non-biologists will find parts of his presentation heavy going. As a professing Christian of conservative theological bent, I find his discussion of the relationship between science and Christian faith basically sound.

Nonetheless, as Asher (p. xiv) recognizes, few youngearth creationists (who believe that God created the universe and its contents in 6 days, less than 10 millennia ago, as told in the Bible's first two chapters) or proponents of intelligent design (who argue that God demonstrably designed many of the ancestors of today's organisms) will read this book, let alone be convinced by it. They object to evolutionary theory in the name of science, but their objections are driven by their religious beliefs. With sympathy, Asher discusses various bases for their religious objections.

Asher (p. xv) recognizes that some people have more rational grounds for rejecting evolution by natural selection. He dismisses the slander that William Jennings Bryan was a young-earth creationist, showing that he rejected natural selection because school textbooks used that idea to promote social injustice. Indeed, offensive 'utopias' promoted by reputable scientists in the name of evolutionary theory may still raise up anti-evolutionists (Midgley 2002). Asher, however, seems not to realize how many Christians oppose Darwin's ideas because they depend on Paley's argument from design to

Correspondence: bufotyphonius@gmail.com

Smithsonian Tropical Research Institute, Apartado 0843-03092, Balboa, Ancon, Republic of Panama convince unbelievers by proofs. I beg the indulgence of atheist readers, but to converse meaningfully on evolution with intelligent designers, criticism, based on the nature of God as revealed in the Gospels' depiction of Jesus, of their desire to 'prove' God, is needed to open the way.

Asher begins his book by explaining why evolutionary theory is compatible with Christian belief. He distinguishes 'agency', the 'why' - by which he means Aristotle's final cause, or Aquinas's first cause - from 'cause', the 'how', by which he means Aristotle's efficient cause or Aquinas's secondary causes. Agency can represent God's creative intent and sustaining activity, but God's agency is not detectable, or meant to be detectable, by any form of scientific test. In the biologist Dorit's (1997) fine phrase, 'The hand of God may be all around us, but it is not, nor can it be, the task of science to dust for fingerprints'. The theologian John Polkinghorne (2004) noted: 'The eye of faith may... discern God at work, but the peculiarity of that fact cannot be demonstrated by empirical analysis'. Asher's 'causes', the laws of physics, mutation and genetic variation, differential reproduction, differential mortality, and the like - are the stuff of science, which can be studied without reference to the direct interposition of God. 'Intelligent design' is therefore outside the realm of natural science, because, as Aquinas saw, natural science deals only with secondary - material - causes and their consequences (Summa Theologica, Part I, Question 84, Article 1). Asher's distinction between agency and cause, however, will discomfort those biologists who confuse it with Ernst Mayr's distinction between ultimate causes (the adaptive why) and proximate causes (the mechanistic/ physiological how), which are both testable. Asher may need to draw his distinction more carefully. Moreover, some natural theologians and proponents of 'intelligent design' will object to declaring God's agency untestable an objection I will discuss later. Finally, Asher's approach will put off those who think that second causes leave no place for God's providence. Blaise Pascal (1976, p. 72)

\section{Springer}


said that Descartes's mechanistic determinism could not avoid letting God give a flick of a finger (une chiquenaude) to set the world going, but after that, God had nothing to do. In my teens, I lost my faith for a few years because I thought Newton's laws implied that the positions and velocities of all the universe's elementary particles at one time would determine their positions and velocities, and thus the behavior of everything in the universe, forever after. Such determinism would exclude God's providence, making belief in the Biblical God illogical. I did not realize that the data needed to test for such determinism are inaccessible to any human being: postulating such determinism, with its implied limits on God's freedom and ours, can only be an act of faith. Nonetheless, many Christians and Muslims clearly fear that the 'determinism' of natural selection from random mutation eliminates God's power to influence the direction of evolution.

Asher next presents some of the evidence for evolution. He emphasizes findings from the fossil record: the origin of mammals, the gradual transformation of reptilian jaw-joint bones into mammalian ear-bones, the stages by which elephants evolved from mammals of very ordinary size and shape, and the stages by which seagoing whales evolved from terrestrial ancestors of hippopotami. He notes that today, all mammals, unlike reptiles, drink their mothers' milk when very young, cease growth at or soon after sexual maturity, and have a single jaw-bone and three small ear-bones. Moreover, all modern mammals, unlike any modern reptile, descend from furry quadrupeds with limbs under their bodies (rather than splayed outward as in reptiles) and teeth differentiated for different functions, such as incisors, canines, or molars. Different mammal characteristics, however, evolved at different times. Two hundred and fifty million years ago some quadrupeds had differentiated teeth and limbs under their bodies, like mammals, but, like reptiles, they had several bones in their jaw and just one in their ear, and they never stopped growing. Asher observes that these fossils combine features now considered distinctive of different major groups. Other fossils also do so. Archaeopteryx, a no longer missing link between reptiles and birds, had the teeth and tail of a reptile, and the wings and feathers of a bird. Rodhocetus, a no longer missing link between artiodactyls (even-toed ungulates) and modern whales, had the ankle bones, legs, and feet of an artiodactyl, but its feet served as paddles, and, like modern whales, it used its tail when swimming, and lived by catching fish in relatively deep water. Unfortunately, the book's photographs (many of which should have been replaced by drawings), are often not clear enough to illumine the text.

Asher also emphasizes how paleontologists, comparative anatomists, and molecular biologists infer very nearly the same sequences of divergence from data in their various fields. All agree that fish diverged from the ancestors of human beings before amphibians; then reptiles (which gave rise to birds), then pigs, then lemurs, then monkeys, and finally, chimpanzees. More recent divergence implies closer relationship: we are more closely related to chimps than to lemurs. Indeed, one of Darwin's triumphs was explaining the pattern of relationships suggested by the 'natural classifications' of traditional systematists. Asher cites a wonderful instance of how evidence for evolution converges from different lines of enquiry. The fossil record reveals the stages by which jaw-bones in ancient reptiles became ear-bones in modern mammals. In 1837, a German anatomist showed that ear-bones in mammals, like the jaw-joint bones in frogs and birds, develop from cartilage in the first two of the visceral arches separating successive gill slits in the tadpole-like stage of their respective embryos, a phenomenon that only makes sense in the light of their common ancestry. Later, a molecular biologist, Abbie Tucker, found that a gene expressed in the embryonic visceral-arch precursors of a mouse's ear-bones is also expressed in the embryonic visceral-arch precursors of a bird's jaw-bone. The jaw-bone-ear-bone transition shows how features evolved for one function often become useful, and become selected for (transferred to), another. Darwin emphasized the importance in evolution of such transfers of function, which, as Asher emphasizes, have enabled us to understand how many complex characteristics could evolve.

Asher's account should suffice to establish evolution as fact. He acts, however, as if the fact of evolution comes very near to establishing natural selection as its cause. This is wrong. Evolution states that all life descended, with innumerable divergent modifications, from common ancestors. Understanding how this happened - the origin of variation and whether, and if so how, natural selection spread better adapted variants, is a separate question (Fisher 1930). In the 1920s, most biologists accepted evolution as a fact but rejected natural selection as its cause. By showing how sexual reproduction and other features of Mendelian genetic systems implied that natural selection of random mutations would cause both adaptation and speciation, Fisher (1930) provided the impetus for the 'modern evolutionary synthesis' between genetics and evolution, although it took decades for the full magnitude of his achievement to sink in. Dobzhansky (1937) and Mayr (1942) enabled most biologists to understand how one species could evolve into two non-interbreeding populations which, by definition, would be separate species. David Lack (1947); Colin Pittendrigh (1950); Robert MacArthur (1958), and many others showed that the differences between related species were adaptive, a circumstance earlier doubted by as 
committed a Darwinian as Sewall Wright (1931, p. 154). Gerhart and Kirschner (1997); Carroll (2005), and various others finished Fisher's job, incorporating developmental biology into the evolutionary synthesis and establishing in satisfying detail how genetic systems are organized to enhance the frequency of favorable mutations and the effectiveness of natural selection in achieving adaptation. Margulis (1993) showed how an unusual but crucial event, symbiogenesis (the transformation of bacterial parasites into cooperative partners, mitochondria, within one-celled archaea, and the subsequent welding of archaea and their mitochondria into coherent individuals called eukaryotes), caused a major evolutionary transition. Such work convinced most biologists that natural selection drove adaptive evolution.

Evolutionary theorists also have a criterion for judging whether adaptation is the product of natural selection: natural selection favors those features that serve the common good of the autosomal genome, the common interest of those genes on chromosomes with homologous counterparts (as opposed to genes on the 'sex chromosomes'). This common good is served most distinctively by the fairness of meiosis, how resources are partitioned between producing offspring of the two sexes, and by response to genealogical kin selection (Grafen 2006; Leigh 2010). Asher presents no evidence that distinguishes natural selection as the cause of adaptive evolution - a dangerous gap in his argument.

As various types of evidence converge, and as more 'missing links' are found, the case for evolution grows ever stronger. Thanks in part to the prodding questions of intelligent designers, the case for natural selection as evolution's director is nearly as strong. Meléndez-Hevia et al. (1996); Miller (2004); Finnigan et al. (2012), and others are showing that various examples of 'irreducible complexity' - structures which 'could not have evolved' by a succession of intermediate stages, each more advantageous than the last - are in fact reducible. Usually, it is clear that components of such structures originally evolved for other purposes, although we are still far from knowing all the stages by which these structures evolved. Perhaps intelligent designers' questions about 'irreducible complexity' in bacterial biochemistry will find their answers in mechanistic studies of the origin of life (cf. Martin and Russell 2007). No amount of evidence, however, convinces committed creationists of evolution. Instead, they deny that natural selection of random mutations can produce complex adaptation, asserting that only God can do so. Their argument's vulgar form dismisses adaptation by natural selection of random mutations as sheer chance, likening it to the assembly of a jumbo jet by a hurricane crossing a junkyard (Asher, p. 78). Artificial selection, however, which works on the same sorts of variation as its natural counterpart
(Darwin 1859), has effected stunning changes in domesticated plants and animals that have helped to feed a hungry world. Natural selection, like its artificial counterpart, is a constructive process, each step building on a previous change, a feature which, as Asher observes, anti-Darwinians tend to ignore. According to Fisher (1930, p. 37), the claim that:

'Natural selection depends on a succession of favourable chances' is 'more in the nature of an innuendo than a criticism, for it depends for its force on the ambiguity of the word chance, in its popular uses. The income derived from a Casino by its proprietor may, in one sense, be said to depend on a succession of favorable chances, although the phrase contains a suggestion of improbability more appropriate to the patrons of his establishment. It is easy... to perceive the difference between a succession of favourable deviations from the laws of chance, and ... the continuous and cumulative action of those laws. It is on the latter that the principle of natural selection depends.'

In sum, natural selection of random mutations is a principle of order, leading to adaptation, not a principle of disorder, leading to chaos.

Intelligent design advocates accept the universe's great age, and some accept the fact of evolution: they, too, balk at the power of natural selection of random mutations to yield observed adaptation. Focusing on this issue has shifted the debate about natural selection from pitting the word of scientists against the Bible's - a futile exercise - to a thesis that can be discussed rationally. Intelligent designers revealed a weakness in evolution teaching - neglect of how genetic systems are organized to allow adaptation to evolve - for which Kirschner and Gerhart (2005) and others provided a remedy. On the other hand, evolutionary biologists can now ask why, if God miraculously designed each species for its role in life, they are designed, as if by natural selection, to favor the common good of their autosomal genomes.

Despite this shift, the debate remains sterile. Behe (1996) wrote a book denying that natural selection could produce the complex array of chemical reactions on which bacteria depend. I refuse to fault Behe for asking this question: 25 years earlier, a renowned biochemist, an atheist, confessed the same view to me. Yet, judging by Coyne (1996) and Cavalier-Smith (1997), Behe's reviews were not just critical, but downright hostile. What happened? First, Behe (1996, p. 233) celebrated the 'proof' that cells are intelligently designed as 'one of the greatest achievements in the history of science'. Did he not realize that most scientists view invoking miracles to explain natural phenomena as a confession of utter 
defeat? Second, enrolling Niles Eldredge, Jerry Coyne, and Stuart Kaufman on the list of anti-Darwinians (Behe 1996, p. 27ff) arouses memories of the truth-twisting tactics of professional creationist speakers mentioned by Asher (p. 141), and detailed by Eldredge (2000, pp. 17f, 129ff). Could Behe really believe that Coyne was antiDarwinian? Third, the theory of evolution by natural selection makes a cornucopia of distinctive, often precise, well-confirmed predictions ranging from the nature of adaptation to biogeographic patterns such as presence of most of an island's residents' nearest relatives on the nearest continent, and the contrasts between island and mainland ecosystems (Darwin 1859). Dobzhansky's dictum that 'nothing in biology makes sense except in the light of evolution' is amply justified (Losos 2011). Abandoning a theory rich enough in predictive power to be the unifying principle of biology because one cannot imagine a sequence of steps by which selection could achieve this or that complex adaptation places a premium on one's powers of imagination that most evolutionary biologists find unacceptable.

Unfortunately, Darwinians' studied incuriosity about why Behe wrote his book parallels Richard Cheney's refusal of sympathetic curiosity about the motives of those who destroyed the World Trade Center, and the studied incuriosity many intelligent designers feel about the workings of nature, which they, Asher and I all believe to be God's creation - which He pronounced good. Such incuriosity about one's opponents, or one's surroundings, is equally self-defeating for debaters, scientists, politicians and generals: it does not prompt effective behavior.

Evolutionary biologists must understand that no evidence is likely to convince a creationist or intelligent designer who believes that accepting evolution by natural selection means abjuring their faith in a meaningful God. Although much Christian witness (acting out Christian faith in deed or word), including the ways some Christians treat those who disagree with them, hardly attracts sympathetic understanding, those acquainted with genuine Christian hope will readily understand why no one would want to lose it. It is accordingly counterproductive to announce, with Monod (1970) and Dawkins (1976), the 'scientific' conclusion that God cannot exist and the universe is meaningless. Dawkins (1976, p. 2) is unwise and wrong to assert that "nature red in tooth and claw" sums up our understanding admirably' and that 'a predominant quality to be expected in a successful gene is ruthless selfishness. This gene selfishness will usually give rise to selfishness in individual behavior.' Dawkins's attitude has many parallels among evolutionary biologists. This attitude brings to mind an observation of Bernanos (1953, p. 279):
'Were the creation simply the work of intelligence, then human intelligence could do better than discovering some of its laws in order to exploit this knowledge as if one might use a machine. Human intelligence would not be always ready to condemn the creation in the name of logic or justice. But creation is a work of love. Reduced to its own resources, intelligence believes that it can find in nature only indifference and cruelty, but the cruelty it sees in nature is its own... Intelligence is more cruel than nature' (translated by the reviewer).

Darwin, however, saw meaning in nature and evolution. His view of nature is far more appealing, and far better rooted in evolution, than Dawkins's. Darwin realized that selection often favored social behavior, and asserted that 'our moral sense is fundamentally identical with the social instincts; and in the case of the lower animals it would be absurd to speak of these instincts as having been derived from selfishness' (Darwin 1871, pp. 97f). Indeed, Darwin viewed our social instincts, our mutual concern for fellow group members, as adaptations for group life inherited from our social ancestors. Adam Smith anticipated Darwin by showing how competition can bring forth the most complex, intricate, and extensive mutualisms on this earth: human economies. It is no accident that David Sloan Wilson, who emphasizes, quite rightly, the many forms of cooperation that influence evolution, has helped teach one of the few university courses that actually convince creationists of Darwinism (Wilson 2007, pp. 7ff).

Intelligent design and 'scientific creationism', however, are not merely scientific errors based on revulsion at the consequences of a grossly oversimplified and misinterpreted version of evolutionary theory. They are based on a theological mistake (this criticism does not apply to those who are creationists out of simple faith in the Bible). First, 'proving' the existence of God to children in public schools by demonstrating that species were intelligently designed would allow intelligent designers to bludgeon unbelievers by proofs rather than taking the trouble to win them over by showing forth the love of Christ. As Pascal (1976, p. 121) points out, this is a most unbiblical procedure. Digging more deeply, Bernanos (1953, p. 273f) argued:

'If God had wished to win us by miracles, he certainly would have not stopped with Cana, or even the resurrection of Lazarus. It would have cost Him nothing to impose Himself by much more extraordinary, indeed cosmic, prodigies. Instead, what the Holy Gospels tell us of the phenomena marking the death of the Savior, the darkening of the sun, the rending of the veil in the temple, the quaking of the 
earth, are small potatoes compared with the bomb at Hiroshima. But let's go further and think a bit. Why win us back by using miracles to force our will? Speaking of constraint, it would have been far easier to avoid losing us by according our wills with His once for all, like the planet constrained to circle around the sun. But God did not want to make us irresponsible, that is to say, incapable of love, for there is no responsibility without freedom and love is a free choice, or it is nothing.' (Translated by the reviewer)

This statement does not imply that Christianity demands an arbitrary, unreasonable leap of faith. Pascal (1976, p. 122f) rightly said 'Faith is different from proof: one is human, the other is a gift from God. "The just shall live by faith": it is this faith that God puts in one's heart: "faith comes by hearing". He often does so with the help of proofs, but this faith is in one's heart, and makes one say not "I know" but "I believe".' (translated by the reviewer). Arguments from design, such as the precise adaptation of the laws of nature that makes our universe a suitable home for life, have helped people to faith. Such arguments, however, are never coercive (Polkinghorne 2004): they do not exempt one from the need, or the freedom, to choose. Moreover, these arguments promise a Creator, but do not imply God's providence. Since Christianity first spread by preaching Christ, why do Christians not base their arguments on His life and work? Focus on Gospel accounts of His doings and teaching (Yoder 1972) has changed lives and forged saints. And, although the occasional Episcopal bishop has denied His resurrection to conform to the world of science, denying His resurrection or the genuineness of His teaching as recorded in the Gospels requires accepting other troubling implausibilities (Wright 1996, 2003). Wright's arguments are not proofs; they only show that accepting Christianity does not defy reason or historical evidence. In the end, opting for faith is far more like choosing whom to marry than choosing the best explanation for a set of scientific data. Knowledge plays an integral role in the choice, but the choice should be based on love.

Phillip Johnson, the best-known proponent of intelligent design at the turn of the millennium (Eldredge 2000), reveals the fears that drive the thinking of many intelligent designers and 'scientific creationists'. He promotes intelligent design because he fears that methodological naturalism ( $\mathrm{MN}$, his term for science based entirely on second causes), when 'understood profoundly', makes theism 'intellectually untenable' (Johnson 1995). In particular, Johnson (1995, p. 211) fears that if employing $\mathrm{MN}$ is the only way to reach true conclusions about the history of the universe, and if the attempt to provide a naturalistic history of the universe has continually gone from success to success, and if even theists concede that trying to do science on theistic premises always leads nowhere or into error..., then the likely explanation for this state of affairs is that naturalism is true and theism is false'. On the same page, he contemptuously dismisses the possibility that 'God actively directs the evolutionary process but (for some inscrutable reason) does so in a way that is empirically imperceptible'. Johnson seems unable to accept that God would create in a way that does not coerce belief.

The 'evolution-creation wars', moreover, reflect a clash between two views of God, already foreshadowed by the conflicting views of Johnson and Polkinghorne on the empirical perceptibility of God's influence on nature. St. Thomas Aquinas describes the clash:

'Some have understood God to work in such a way that no created power has any effect on things, but that God alone is the immediate cause of everything wrought... But this is impossible. First, because the order of cause and effect would be taken away from created things, and this would imply lack of power in the Creator' (Summa Theologica, Part I, Question 105, Article 5).

Polkinghorne (2004) extends the logic of Aquinas to evolution:

'Although the Creator could ... have brought into being a ready-made world, God has in fact "brought" into being a creation that could make itself... The Creator is not the Cosmic Tyrant whose unrelenting grip holds on tightly to all. Such an enslaved world would not be the creation of a loving God. Rather, creation is allowed to be itself and make itself.'

Francisco Ayala (2007, pp. 4-5) mentions how, in Franco's Spain, his seminary professors welcomed Darwinism so that they could avoid blaming God for malignant creatures like malaria mosquitoes. Polkinghorne, however, has probed much deeper. Curiously, Fisher (1950), also a Christian, anticipated Polkinghorne. Fisher called a process creative if it involved successive choices between alternatives not themselves fully predetermined and denied creative status to development by deterministic law. Natural selection chooses between alternatives that are not fully predetermined, thereby imparting information to surviving organisms' descendants on how to cope with their environment. Fisher therefore considered selection creative. He saw the theory of natural selection as placing the creative causes shaping evolution 'in the actual life of living things... especially in the vital drama of the success or failure of each of their 
enterprises' (Fisher 1950, p. 17). Therefore, 'living things themselves are the chief agents of the Creative activity... they work their effect by doing or dying...' (Fisher 1950, p. 20), although most do so without conscious choice or foresight. Just as Aquinas saw created things as endowed with causality, so Fisher and Polkinghorne saw living populations as endowed with the freedom to evolve.

Such freedom, however, entails a cost. Evil among human beings arises from God creating us with free will: as Bernanos (1953, p. 280) remarked 'The scandal of the universe is not suffering but freedom. God made his creation free: that's the root scandal, from which all the other scandals result' (translated by the reviewer). Dostoyevsky's fable of the Grand Inquisitor in The Brothers Karamazov, and the Spanish bishops' and clergy's very real complicity in the shooting of truckloads of randomly chosen peasants without trial to terrorize the others into obeying Franco's government, confessing their sins to a priest, and attending Easter communion (Bernanos 1938) illustrate how many professing Christians disapprove of God creating us free. Similarly, evil in the natural world arises in part from the freedom to evolve: natural selection is driven by the early death, or failure to reproduce, of many of the less adapted.

The religiously inspired attack on evolutionary theory damages Christianity in many ways. First, blaming evolutionary biology for atheism and immorality merely distracts attention from the devastating impact of poor Christian witness, especially the evil things done in Christ's name. Just as the shifty tactics of professional creationists promotes atheism among evolutionary biologists, so the support of many professing Christians for the Iraq war in hopes of spreading Christianity there made this faith repulsive in many people's eyes. Second, the attempt of creationists and intelligent designers to erode the constitutional separation between church and state by making public schools teach doctrines meant to buttress religious belief does Christianity no good. Throughout history, trying to make the state serve the church has always ended in the church serving, and being corrupted by, the state. Third, many deny evolution to deny our relationship to the rest of creation. Ignoring this relationship left it to the atheist Voltaire to remind Christians that other animals have the same organs, nerves, and so on that we do and ask how they could not feel pain as we do (Midgley 1983). In the second chapter of Genesis, the Bible teaches that people are the lords and stewards of Creation, whose duty it is to tend and care for it. Yet, denying the relationship between human beings and other animals in order to buttress their faith left it to Voltaire to mention facts bearing crucially on the responsibilities of such lordship. This is because, to excuse this denial, many Christians dogmatically deprecate the abilities of other animals to make tools, distinguish between fair and unfair treatment, anticipate or even feel pain, even the ability of a dog to anticipate the pleasures of a walk. In essence, they deprecate the Creator's generosity - an odd way to praise Him. Many of those Christians who insist that the earth and its resources were created only for us to exploit in any way we choose are not Christ-like lords and stewards of Creation.

Intelligent designers' fear of evolutionary biology arises from a siege mentality that reveals a lack of faith in God. Siege mentality has no place in genuine Christianity. It is joyless. Absence of joy, especially when born of lack of faith, engenders poor Christian witness. Bernanos (1938, pp. 234f) imagines an atheist speaking to a congregation gripped by siege mentality: 'When you leave the confessional, you are in "a state of grace"... We wonder what you do with the grace of God. Should it not shine forth from you? Where the devil do you hide your joy?' One of life's joys is that of finding things out and discovering their marvelous order. Darwin experienced a full measure of this joy. Asher effectively communicates the joy of seeing how much of biology makes sense in the light of evolution. Christians sharing the medievals' confidence that science rightly done cannot conflict with the Bible rightly interpreted can share this joy. This joy, moreover, is essential to modern life. 'In spite of what has recently been written to the contrary, it is hardly to be doubted that most of human progress, insofar as it depends on purely intellectual factors, is ultimately based on the mental pleasure arising from seeing new facts as special cases of generalizations, or new generalizations arising from old and new facts.' (Hutchinson 1953, p. 145). Let no one's fears take this joy from us.

\section{Competing interests}

The author declares that he has no competing interests.

Received: 18 February 2013 Accepted: 18 February 2013 Published: 18 April 2013

\section{References}

Ayala, FJ. (2007). Darwin's Gift to Science and Religion. Washington, DC: Joseph Henry Press.

Behe, MJ. (1996). Darwin's Black Box: The Biochemical Challenge to Evolution. New York, NY: Simon and Schuster.

Bernanos, G. (1938). Les grandes cimetières sous la lune. Paris: Plon.

Bernanos, G. (1953). Nos amis les saints. In G Bernanos (Ed.), La Liberté pour quoi faire? (pp. 261-289). Paris: Gallimard.

Carroll, SB. (2005). Endless Forms Most Beautiful: The New Science of Evo Devo. New York, NY: W. W. Norton.

Cavalier-Smith, T. (1997). The blind biochemist (a review of Darwin's Black Box). Trends in Ecology \& Evolution, 12(4), 162-163.

Coyne, JA. (1996). God in the details (a review of Darwin's Black Box). Nature, 383, 227-228.

Darwin, C. (1859). On the origin of species by means of natural selection. London: John Murray.

Darwin, C. (1871). The descent of man, and selection in relation to sex. London: John Murray.

Dawkins, R. (1976). The Selfish Gene. Oxford: Oxford University Press.

Dobzhansky, T. (1937). Genetics and the Origin of Species. New York, NY: Columbia University Press. 
Dorit, R. (1997). Molecular evolution and scientific enquiry, misperceived (a review of Behe, Darwin's Black Box). American Scientist, 85, 474-475.

Eldredge, N. (2000). The Triumph of Evolution and the Failure of Creationism. New York, NY: Henry Holt \& Co.

Finnigan, JC, Hanson-Smith, V, Stevens, TH, \& Thornton, JW. (2012). Evolution of increased complexity in a molecular machine. Nature, 481(7381), 360-364.

Fisher, RA. (1930). The Genetical Theory of Natural Selection. Oxford: Clarendon Press.

Fisher, RA. (1950). The Eddington Memorial Lecture. Cambridge: Cambridge University Press.

Gerhart, JC, \& Kirschner, MW. (1997). Cells, Embryos and Evolution: Toward a Cellular and Developmental Understanding of Phenotypic Variation and Evolutionary Adaptability. Boston, MA: Blackwell Science.

Grafen, A. (2006). Optimisation of inclusive fitness. Journal of Theoretical Biology, 238(3), 541-563.

Hutchinson, GE. (1953). The Itinerant Ivory Tower. New Haven, CT: Yale University Press.

Johnson, PE. (1995). Reason in the Balance: The Case Against Naturalism in Science, Law and Education. Downers Grove, IL: Intervarsity Press.

Kirschner, MW, \& Gerhart, JC. (2005). The Plausibility of Life: Resolving Darwin's Dilemma. New Haven, CT: Yale University Press.

Lack, D. (1947). Darwin's Finches. Cambridge: Cambridge University Press.

Leigh, EG, Jr. (2010). The evolution of mutualism. Journal of Evolutionary Biology, 23(12), 2507-2528.

Losos, JB (Ed.). (2011). In the Light of Evolution. Greenwood Village, CO: Roberts and $\mathrm{Co}$.

MacArthur, RH. (1958). Population ecology of some warblers of northeastern coniferous forests. Ecology, 39(4), 599-619.

Margulis, L. (1993). Symbiosis in Cell Evolution. New York, NY: W. H. Freeman.

Martin, W, \& Russell, MJ. (2007). On the origin of biochemistry at an alkaline hydrothermal vent. Philosophical Transactions of the Royal Society of London Series B, 362(1486), 1887-1925.

Mayr, E. (1942). Systematics and the Origin of Species. New York, NY: Columbia University Press.

Meléndez-Hevia, E, Wadell, TG, \& Cascante, M. (1996). The puzzle of the Krebs citric acid cycle: assembling the pieces of chemically feasible reactions, and opportunism in the design of metabolic pathways during evolution. Journal of Molecular Evolution, 43(3), 293-303.

Midgley, M. (1983). Animals and Why they Matter. Athens, GA: University of Georgia Press.

Midgley, M. (2002). Evolution as a Religion. New York, NY: Routledge.

Miller, KR. (2004). The flagellum unspun: The collapse of "irreducible complexity. In WA Dembski \& M Ruse (Eds.), Debating Design: From Darwin to DNA (pp. 81-97). New York, NY: Cambridge University Press.

Monod, J. (1970). Le Hasard et la Necessité. Paris: Éditions de Seuil.

Pascal, B. (1976). Pensées. Paris: Garnier-Flammarion.

Pittendrigh, CS. (1950). The ecotypic specialization of Anopheles homunculus and its relation to competition with A. bellator. Evolution, 4(1), 64-78.

Polkinghorne, J. (2004). The inbuilt potentiality of creation. In WA Dembski \& M Ruse (Eds.), Debating Design: From Darwin to DNA (pp. 246-260). New York, NY: Cambridge University Press.

Wilson, DS. (2007). Evolution for Everyone. New York, NY: Dell Press.

Wright, S. (1931). Evolution in Mendelian populations. Genetics, 16(2), 97-159.

Wright, NT. (1996). Jesus and the Victory of God. Minneapolis, MN: Fortress Press.

Wright, NT. (2003). The Resurrection of the Son of God. Minneapolis, MN: Fortress Press.

Yoder, JH. (1972). The Politics of Jesus. Grand Rapids, MI: W. B. Eerdmans.

doi:10.1186/1936-6434-6-15

Cite this article as: Leigh: Does evolution compromise Christian faith? R. J. Asher's Evolution and Belief. Evolution: Education and Outreach 2013 6:15.

\section{Submit your manuscript to a SpringerOpen ${ }^{\circ}$ journal and benefit from:}

- Convenient online submission

- Rigorous peer review

- Immediate publication on acceptance

- Open access: articles freely available online

- High visibility within the field

- Retaining the copyright to your article

Submit your next manuscript at $\gg$ springeropen.com 